\title{
SCREENING DAN KARAKTERISASI PEKTINESTERASE SEBAGAI ENZIM POTENSIAL DALAM KLARIFIKASI SARI BUAH JERUK KEPROK GARUT (Citrus nobilis var.chrysocarpa)
}

\author{
Screening and Characterization of Pectinesterase as A Potential Enzyme in Keprok Garut Citrus Juice \\ (Citrus nobilis var.chrysocarpa) Clarification
}

\author{
Rohula Utami, Esti Widowati, Arifah Rahayu \\ Program Studi Ilmu dan Teknologi Pangan, Fakultas Pertanian, Universitas Sebelas Maret, \\ Jl. Ir. Sutami 36 A, Kentingan, Surakarta 57126 \\ Email : rohula_utami@yahoo.com
}

\begin{abstract}
ABSTRAK
Tujuan dari penelitian ini adalah untuk melakukan screening bakteri penghasil enzim pektinesterase (PE) yang berpotensi dalam proses klarifikasi sari buah jeruk keprok garut (Citrus nobilis var microcarpa) serta mengetahui karakteristik enzim pektinesterase yang dihasilkan (pH optimum, suhu optimum, kestabilan $\mathrm{pH}$ dan suhu, serta nilai $\mathrm{K}_{\mathrm{M}}$ dan $\mathrm{V}_{\text {maks }}$ ). Hasil screening didapatkan isolat AR 2, AR 4, AR 6, dan KK 2 sebagai isolat penghasil enzim pektinesterase yang berpotensi dalam proses klarifikasi sari buah jeruk keprok garut. Aktivitas enzim pektinesterase isolat AR 2, AR 4, AR 6 dan KK 2 berturut-turut optimum pada $\mathrm{pH}$ 8; $\mathrm{pH}$ 7,5; pH 8,5; dan pH 6,5, serta stabil pada pH 4-9, pH 4-9, $\mathrm{pH}$ 6-9, dan $\mathrm{pH}$ 3-8. Suhu optimum enzim pektinesterase isolat AR 2, AR 4, AR 6, dan KK 2 berturut-turut adalah $55^{\circ} \mathrm{C}, 60^{\circ} \mathrm{C}, 55^{\circ} \mathrm{C}$, dan $60^{\circ} \mathrm{C}$. Enzim pektinesterase isolat AR 2 stabil pada suhu $30-50^{\circ} \mathrm{C}$ dan inaktif pada suhu $80^{\circ} \mathrm{C}$, enzim pektinesterase isolat AR 4 dan KK 2 stabil pada suhu $30-60^{\circ} \mathrm{C}$ dan inaktif pada suhu $90^{\circ} \mathrm{C}$, sedangkan enzim pektinesterase isolat AR 6 stabil pada suhu $30-60^{\circ} \mathrm{C}$ namun belum inaktif pada suhu $90^{\circ} \mathrm{C}$. Nilai konstanta Michaelis-Menten $\left(\mathrm{K}_{\mathrm{M}}\right)$ enzim pektinesterase isolat AR 2, AR 4, AR 6, dan KK 2 berturut-turut adalah 0,604; 0,338; 0,971; dan 0,392 $\mathrm{mg} / \mathrm{ml}$. Sedangkan nilai kecepatan maksimum $\left(\mathrm{V}_{\text {maks }}\right)$ enzim pektinesterase isolat AR 2, AR 4, AR 6, dan KK 2 berturut-turut adalah 1,218; 0,826; 0,969; dan 1,080 U/ml. Enzim pektinesterase isolat KK 2 memiliki karakteristik yang paling sesuai untuk aplikasi dalam klarifikasi sari buah jeruk keprok garut dibandingkan dengan enzim pektinesterase isolat lainnya.
\end{abstract}

Kata kunci: Enzim, klarifikasi, pektin, pektinesterase, jeruk keprok garut

\begin{abstract}
The objective of this research was screening of pectinesterase (PE) producing bacteria which are potential in clarification of keprok garut citrus juice (Citrus nobilis var microcarpa) and characterization of the resulted pectinesterase (optimum $\mathrm{pH}$ and temperature, $\mathrm{pH}$ and thermal stability, $\mathrm{K}_{\mathrm{M}}$ and $\mathrm{V}_{\text {maks }}$ ). The screening result showed that enzyme of isolates AR 2, AR 4, AR 6, and KK 2 was found to be a potential enzyme for clarification of keprok garut citrus juice. Enzyme pektinesterase of isolates AR 2, AR 4, AR 6, and $\mathrm{KK} 2$ had optimum $\mathrm{pH}$ at 8; 7.5; 8.5; and 6.5 and stable at $\mathrm{pH} 4-9$, 4-9, 6-9, and 3-8. The optimum temperature enzyme of isolates AR 2 and $\mathrm{AR} 6$ were $55^{\circ} \mathrm{C}$ and that of AR 4 and $\mathrm{KK} 2$ were $60^{\circ} \mathrm{C}$. Enzyme of isolate $\mathrm{AR} 2$ was stable at $30-50^{\circ} \mathrm{C}$ and inactive at $80^{\circ} \mathrm{C}$, AR 4 and $\mathrm{KK} 2$ were stable at $30-60^{\circ} \mathrm{C}$ and inactive at $90^{\circ} \mathrm{C}$ whereas AR6 was stable at $30-60^{\circ} \mathrm{C}$ and still wasn't inactive at $90^{\circ} \mathrm{C}$. $\mathrm{K}_{\mathrm{M}}$ value of isolates AR 2 , AR 4, AR 6, and KK 2 were 0.604; 0.338; 0.971; and $0.392 \mathrm{mg} / \mathrm{ml} \mathrm{V}_{\text {maks }}$ value of isolates AR 2, AR 4, AR 6, and KK 2 were $1.218 ; 0.826 ; 0.969$; and $1.080 \mathrm{u} / \mathrm{ml}$. Pectinesterase enzyme of isolates KK 2 was found to be the most potential enzyme for clarification of keprok garut citrus juice.
\end{abstract}

Keywords: Clarification, enzyme, keprok garut citrus, pectin, pectinesterase 


\section{PENDAHULUAN}

Jeruk keprok garut (Citrus nobilis var. chrysocarpa) merupakan jeruk lokal Indonesia yang berdasarkan Keputusan Menteri Pertanian No: 760/KPTS.240/6/99 telah ditetapkan sebagai Jeruk Varietas Unggul Nasional. Data produksi jeruk keprok di kabupaten Garut mengalami peningkatan dari 117.146 Kw pada tahun 2011 menjadi $144.553 \mathrm{Kw}$ pada tahun 2012 (BPS Kabupaten Garut, 2014). Jeruk keprok garut berkulit buah tipis, kasar, mudah terlepas dan mudah patah sehingga menyebabkan kesulitan pasca panen (Soelarso, 1996). Sebagian besar buah jeruk juga diperdagangkan dan dikonsumsi dalam bentuk segar sehingga pada bulan puncak panen menyebabkan kesulitan dalam penyimpanan (Hanif dan Zamzami, 2012). Oleh karena itu, diperlukan proses pengolahan jeruk keprok garut untuk mengoptimalkan potensi, memperpanjang umur simpan, dan meningkatkan nilai ekonominya.

Salah satu bentuk pengolahan buah yang menjadi tren produk minuman adalah sari buah. Namun, sari buah jeruk cenderung semakin keruh dan kental selama penyimpanan yang disebabkan oleh polisakarida seperti pektin, pati, dan komponen hemiselulosa (Sharma dan Chand, 2012). Sari buah yang keruh merupakan suspensi koloid dari pektin, polisakarida netral yang larut dalam asam, gula (fruktosa, glukosa dan sukrosa), protein, lipid dan mineral. Suspensi tersebut sebagian besar berasal dari jaringan buah yang hancur selama pemprosesan buah (Benitez dan Lozano, 2006). Pektin juga dapat menghambat filtrasi sari buah karena membentuk lapisan gel yang sangat kental (Rai dkk., 2006). Pembentukan gel terjadi akibat adanya ikatan hidrogen antara grup karboksil bebas pada molekul pektin dan antara grup hidroksil molekul lain (Raj dkk., 2012). Pektin dan hemiselulosa juga dapat mengikat komponen fenolik dan protein selama proses dan penyimpanan yang menghasilkan pembentukan senyawa komplek yang irreversible sehingga menyulitkan klarifikasi (Minh, 2014). Oleh karena itu, pada proses industri biasanya dilakukan proses depektinasi menggunakan enzim untuk menghilangkan pektin yang ada dalam sari buah.

Pektinesterase atau Pektin Metil Esterase (PME) atau pektin metoksilase atau pektin dimetoksilase (kode : EC 3.1.1.11) merupakan salah satu enzim pektinase yang biasa digunakan untuk proses depektinasi dalam industri sari buah. Menurut Basak dan Ramaswamy (2001) pektinesterase merupakan enzim yang berpengaruh dalam klarifikasi sari buah jeruk. Pektinesterase mengkatalisis hidrolisis pektin yang ada dalam sari buah jeruk menjadi asam pektat dan methanol. Ikatan silang asam pektat dan ion kalsium meningkatkan berat molekul pektin, mengurangi kelarutan pektin sehingga terjadi flokulasi yang menyebabkan hilangnya kekeruhan pada sari buah dan terjadi klarifikasi spontan (Ingallinera dkk., 2005).

Untuk aplikasi industri, enzim harus stabil dalam kondisi proses. Mikroorganisme termofilik diyakini sebagai alternatif sumber potensial yang baik dari enzim termostabil. Menurut Egas dkk., (1998) enzim dari bakteri termofilik sering memiliki aktivitas katalitik dan stabilitas yang lebih tinggi daripada enzim dari mikroorganisme mesofilik. Penggunaan suhu yang lebih tinggi dalam proses industri dapat mengurangi risiko kontaminasi yang disebabkan oleh mikroorganisme mesofilik (Gaur dkk., 2012). Keuntungan penggunaan enzim termostabil adalah menurunkan jumlah enzim yang dibutuhkan dalam reaksi karena semakin meningkat suhu proses maka tingkat kecepatan reaksi juga meningkat (Zamost dkk., 1991).

Produksi enzim menggunakan mikroba memiliki kelebihan yaitu mikroorganisme dapat berkembang biak dengan cepat, pertumbuhan relatif mudah diatur, enzim yang dihasilkan tinggi sehingga menurunkan biaya produksi dan enzim lebih stabil (Yusak, 2004). Di samping itu, proses produksi tidak dipengaruhi oleh faktor iklim maupun cuaca dan dapat dilakukan manipulasi genetik serta pengaturan lingkungan untuk meningkatkan hasil (Bharwaj dan Garg, 2010). Mikroorganisme yang telah diketahui dapat memproduksi enzim pektinesterase antara lain Phytophthora infestans (Forster, 1988), Erwinia chrysanthemi B341 (Pitkanen dkk., 1992), Saccharomyces cerevisiae (Gainvors dkk., 1994), Lachnospira pectinoschiza (Cornick dkk., 1994), Pseudomonas solanacearum (Schell dkk., 1994), Aspergillus niger (Maldonado dkk., 1994; Maldonado dan Saad, 1998), Lactobacillus lactis subsp. Cremoris (Karan dan Belarbi, 1995), Penicillium frequentans (Kawato dkk., 1999), E. chrysanthemi 3604 (Laurent dkk., 2000), Penicillium occitanis (Hadj-Taieb dkk., 2002), A. japonicus (Semenova dkk., 2003) dan Fusarium asiaticum (Glinka dan Liao, 2011). Jayani dkk. (2005) menyampaikan bahwa sejumlah PE mempunyai berat molekul berkisar antara 35-50 $\mathrm{kDa}$, aktif pada $\mathrm{pH}$ antara $\mathrm{pH} 4,0-8,0$ dan optimum pada suhu $40-50^{\circ} \mathrm{C}$. Pada penelitian Schink dan Zeikus (1983), enzim pektinesterase yang dihasilkan oleh bakteri termofilik Clostridium thermosulfurogenes menunjukkan aktivitas stabil dan aktif pada suhu tinggi yaitu $\geq 60^{\circ} \mathrm{C}$.

Penelitian screening isolat bakteri termofilik penghasil enzim pektinesterase yang bersumber dari limbah sayuran dan limbah kulit jeruk keprok garut ini diharapkan mampu menghasilkan enzim yang berpotensi dalam proses klarifikasi sari buah jeruk keprok garut. Penelitian ini juga bertujuan untuk mengetahui karakteristik enzim pektinesterase yang dihasilkan oleh isolat bakteri termofilik. Aplikasi enzim pektinesterase pada sari buah jeruk keprok garut diharapkan dapat mengurangi kekeruhan dan menurunkan viskositas sari 
buah jeruk, sehingga dapat memberikan peluang pemanfaatan jeruk keprok garut sebagai bahan baku pembuatan minuman sari buah jernih, terutama pada skala industri.

\section{METODE PENELITIAN}

\section{Bahan}

Isolat bakteri yang digunakan dalam penelitian ini didapatkan dari Laboratorium Rekayasa Proses Pengolahan Pangan dan Hasil Pertanian, Fakultas Pertanian, Universitas Sebelas Maret, yaitu isolat AR 1, AR 2, AR 3, AR 4, AR 5, AR 6, AR 7, AR 8, dan AR 9 (isolasi dari limbah sayuran) dan isolat KK 1, KK 2, KK 3, KK 4, dan KK 5 (isolasi dari limbah kulit jeruk keprok garut). Semua isolat merupakan bakteri Gram negatif (kecuali AR 5), endospora negatif, dan katalase positif dengan bentuk bulat atau batang. Klarifikasi sari buah jeruk menggunakan buah jeruk keprok garut yang diperoleh di pasar Gedhe Surakarta. Bahan analisis penelitian antara lain menggunakan yeast extract, Natrium Hidroksida $(\mathrm{NaOH})$, Natrium Hidrogen Fosfat $\left(\mathrm{Na}_{2} \mathrm{HPO}_{4}\right)$, Kalium Dihirogen Fosfat $\left(\mathrm{KH}_{2} \mathrm{PO}_{4}\right)$, Magnesium Sulfat $\left(\mathrm{MgSO}_{4} \cdot 7 \mathrm{H}_{2} \mathrm{O}\right)$, Kalium Klorida (KCl), bacteriological agar, Ammonium Sulfat $\left(\mathrm{NH}_{4}\right)_{2} \mathrm{SO}_{4}$, buffer asetat, buffer fosfat dan buffer Karbonatbikarbonat dari MERCK serta pectin citrus dari SIGMA.

\section{Tahap I. Screening Isolat Penghasil Enzim Pektinesterase yang Berpotensi dalam Proses Klarifikasi Sari Buah Jeruk Keprok Garut}

Screening isolat uji dilakukan berdasarkan pada aktivitas enzim sebagai parameter utama dan jumlah bakteri sebagai parameter pendukung. Pengujian aktivitas enzim dilakukan terhadap enzim kasar yang dihasilkan dengan menggunakan metode Kertesz. Penentuan jumlah bakteri dilakukan dengan pengukuran turbiditas media kultur yang dinyatakan sebagai Optical Density (OD) menggunakan spektrofotometer UVVis (Shimadzu) pada panjang gelombang $400 \mathrm{~nm}$. Selain itu, pengujian kemampuan klarifikasi dari enzim pada sari buah jeruk keprok garut serta pengujian aktivitas depolimerisasi dari enzim pada pektin cair 1\% juga dilakukan untuk mengetahui potensi enzim dalam proses klarifikasi sari buah.

Produksi enzim kasar. Enzim kasar diproduksi dengan cara inokulasi setiap isolat bakteri sebanyak $10 \%$ pada media pektin sitrus cair (yeast ekstrak $1 \mathrm{~g} / \mathrm{L} ; \mathrm{Na}_{2} \mathrm{HPO}_{4} 0,9$ $\mathrm{g} / \mathrm{L} ; \mathrm{KH}_{2} \mathrm{PO}_{4} 1 \mathrm{~g} / \mathrm{L} ; \mathrm{MgSO}_{4} \cdot 7 \mathrm{H}_{2} \mathrm{O} 0,5 \mathrm{~g} / \mathrm{L} ; \mathrm{KCl} \mathrm{0,2} \mathrm{g} / \mathrm{L}$; dan pektin sitrus $1 \mathrm{~g} / \mathrm{L}$ ) dan inkubasi pada suhu $55^{\circ} \mathrm{C}$ selama 24 jam dengan agitasi $144 \mathrm{rpm}$. Enzim kasar diperoleh dengan cara sentrifugasi cairan hasil fermentasi pada kecepatan $6000 \mathrm{rpm}$ pada $4^{\circ} \mathrm{C}$ selama 15 menit dan supernatan yang didapatkan merupakan enzim kasar (Widowati dkk., 2014) dan selanjutnya dilakukan pengujian aktivitas enzim sesuai metode titrasi Kertesz.

Pengujian aktivitas enzim pektinesterase. Prosedur analisis aktivitas enzim pektinesterase dikerjakan dengan metode titrasi Kertesz yang dijelaskan dalam Dixit dkk. (2013) pada suhu $30^{\circ} \mathrm{C}$ dan $\mathrm{pH} 7$. Larutan substrat enzim merupakan citrus pectin (SIGMA) $1 \%$ dalam $0,1 \mathrm{M} \mathrm{NaCl}$ (MERCK) ( $\mathrm{pH} 7$ ). Sebanyak $5 \mathrm{ml}$ larutan substrat pektin dan 0,2 $\mathrm{ml}$ isolat enzim pektinesterase dimasukkan ke dalam tabung reaksi dan $\mathrm{pH}$ diatur kembali pada $\mathrm{pH}$ 7. Campuran diinkubasi pada suhu $30^{\circ} \mathrm{C}$ dalam circulating bath (HAAKE DL 30) selama 30 menit. Setelah itu dilakukan pengukuran $\mathrm{pH}$ akhir, kemudian $\mathrm{pH}$ akhir dikembalikan ke $\mathrm{pH}$ awal dengan penambahan $\mathrm{NaOH}$ (MERCK) 0,01 N. Volume $\mathrm{NaOH} \mathrm{0,01}$ $\mathrm{N}$ yang ditambahkan digunakan untuk penentuan aktivitas enzim. Larutan substrat tanpa penambahan enzim digunakan sebagai kontrol. Satu unit enzim didefinisikan sebagai jumlah enzim yang dapat membebaskan $1 \mu$ mol gugus karboksil bebas per ml per menit pada kondisi uji.

Pengujian kemampuan klarifikasi. Sari buah jeruk keprok garut dipersiapkan untuk pengujian kemampuan enzim pektinesterase dalam klarifikasi. Buah jeruk keprok garut dicuci, dibelah menjadi dua bagian kemudian diperas menggunakan pemeras hand juicer. Sari buah jeruk disaring untuk menghilangkan pulp dan padatan yang ada di dalam sari buah jeruk. Sebanyak $20 \mathrm{ml}$ sari buah jeruk ditambahkan $2 \mathrm{ml}$ enzim pektinesterase dan diinkubasi pada suhu $50^{\circ} \mathrm{C}$ selama 1 jam (Teixeira dkk., 2011). Sari buah jeruk tanpa penambahan enzim digunakan sebagai kontrol. Setelah inkubasi dilakukan pengujian viskositas dengan viskometer Oswald (Karangwa dkk., 2010), total padatan terlarut (TPT) menggunakan hand refractometer (ATAGO) dan transmitansi larutan dengan spektrofotometer UV-Vis (Shimadzu) pada panjang gelombang $600 \mathrm{~nm}$ (Karangwa dkk., 2010).

Pengujian aktivitas depolimerisasi. Aktivitas depolimerisasi diketahui dengan melakukan pengujian enzim dalam pektin cair 1\% (Annisa dan Girish, 2014). Enzim pektinesterase sebanyak 0,2 $\mathrm{ml}$ ditambahkan ke dalam $10 \mathrm{ml}$ pektin cair $1 \%$. Larutan pektin cair 1\% tanpa penambahan enzim digunakan sebagai kontrol. Larutan diinkubasi pada suhu $50^{\circ} \mathrm{C}$ selama 1 jam kemudian dilakukan pengujian viskositas dengan viskometer Oswald dan transmitansi larutan dengan spektrofotometer UV-Vis (Shimadzu) pada panjang gelombang $600 \mathrm{~nm}$.

\section{Tahap II. Produksi dan Pemurnian Parsial Enzim Pektinesterase}

Produksi enzim. Stok inokulum isolat terpilih sebanyak $10 \%$ dipindahkan ke dalam media pektin cair steril 
dan diinkubasi pada suhu $55^{\circ} \mathrm{C}$ dengan agitasi $144 \mathrm{rpm}$. Pemanenan enzim dilakukan pada waktu optimum produksi enzim pektinesterase berdasarkan kurva pertumbuhan dari masing-masing isolat. Enzim kasar didapatkan dengan sentrifugasi suspensi sel dalam media pektin cair dengan kecepatan $6000 \mathrm{rpm}$ suhu $4^{\circ} \mathrm{C}$ selama 15 menit sehingga akan didapatkan supernatan yang merupakan enzim pektinesterase kasar. Enzim kasar tersebut kemudian dimurnikan secara parsial melalui presipitasi ammonium sulfat dan dialisis (Widowati dkk., 2014).

Pemurnian parsial. Pemurnian enzim secara parsial dilakukan dengan presipitasi ammonium sulfat $\left(\left(\mathrm{NH}_{4}\right)_{2} \mathrm{SO}_{4}\right)$ (MERCK) dan dialisis (Janani dkk., 2011). Untuk mengetahui persentase kejenuhan ammonium sulfat terbaik maka dilakukan optimasi pada kejenuhan ammonium sulfat $50 \%, 60 \%, 70 \%$, dan $80 \%$. Jumlah ammonium sulfat yang ditambahkan untuk mendapatkan kejenuhan tersebut ditentukan menggunakan tabel kejenuhan ammoium sulfat. Persentase kejenuhan ammonium sulfat dengan aktivitas enzim pektinesterase tertinggi dipilih untuk pengendapan skala besar.

Penambahan ammonium sulfat ke dalam ekstak enzim kasar dilakukan sedikit demi sedikit sambil diaduk dengan magnetic stirrer dan dibiarkan selama satu malam pada suhu $4^{\circ} \mathrm{C}$. Selanjutnya disentrifugasi $3500 \mathrm{rpm}$, suhu $4^{\circ} \mathrm{C}$, selama 15 menit. Pelet yang diperoleh diresuspensikan dengan $10 \mathrm{ml}$ $50 \mathrm{mM}$ buffer fosfat (MERCK) $\mathrm{pH} 7$ kemudian dimasukkan ke dalam kantong dialisis cut off $12 \mathrm{kDa}$ kemudian direndam dalam gelas kimia yang berisi buffer fosfat $50 \mathrm{mM}(\mathrm{pH} 7,0)$ selama 24 jam suhu $4^{\circ} \mathrm{C}$ sambil diaduk dengan magnetic stirrer. Penggantian buffer fosfat dilakukan sebanyak 3 kali setiap 8 jam sekali dan dicek kandungan ammonium sulfat dalam larutan dengan meneteskan $\mathrm{BaCl}_{2}$. Amonium sulfat akan bereaksi dengan $\mathrm{BaCl}_{2}$ menghasilkan endapan putih $\mathrm{BaSO}_{4}$. Dialisis dihentikan ketika penambahan $\mathrm{BaCl}_{2}$ tidak terbentuk lagi endapan putih. Setelah didapatkan enzim pektinesterase murni parsial kemudian dilakukan karakterisasi enzim pektinesterase meliputi pengujian $\mathrm{pH}$ optimum, suhu optimum, kestabilan $\mathrm{pH}$ dan suhu, serta kinetika enzim berupa $\mathrm{K}_{\mathrm{M}}$ dan $\mathrm{V}_{\text {maks. }}$

Protein enzim (mg protein $/ \mathrm{ml}$ enzim) dianalisis secara spektrofotometri dengan metode Lowry (Sudarmadji dkk., 2010). Absorbansi dilakukan pada panjang gelombang 600 $\mathrm{nm}$ dangan spektrofotometer UV-Vis (Shimadzu). Bovine Serum Albumin (BSA) digunakan sebagai standar protein.

\section{Tahap III. Karakterisasi Enzim Pektinesterase}

Penentuan pH dan suhu optimum enzim pektinesterase. Pengujian $\mathrm{pH}$ optimum enzim dilakukan pada range $\mathrm{pH}$ 5,0-9,0 dengan interval $\mathrm{pH}$ 0,5 (Frittrang dkk.,
1992). Sebanyak 0,2 $\mathrm{ml}$ enzim pektinesterase yang telah didialisis dimasukkan ke dalam $10 \mathrm{ml}$ larutan substrat pektin $1 \%$ dalam $\mathrm{NaCl} 0,1 \mathrm{M}$ yang telah diatur $\mathrm{pH}$-nya. Larutan diinkubasi pada suhu $30^{\circ} \mathrm{C}$ selama 30 menit kemudian reaksi dihentikan dengan menginkubasi larutan kontrol dan sampel pada suhu $100^{\circ} \mathrm{C}$ selama 10 menit selanjutnya dilakukan pengujian aktivitas enzim menggunakan metode Kertesz.

Suhu optimum enzim diuji pada range suhu $30^{\circ} \mathrm{C}$ $60^{\circ} \mathrm{C}$ dengan interval suhu $5^{\circ} \mathrm{C}$ pada $\mathrm{pH} 7$ (Dixit dkk., 2013). Larutan substrat pektin $1 \%$ dalam $\mathrm{NaCl} 0,1 \mathrm{M}(\mathrm{pH}$ 7) sebanyak $10 \mathrm{ml}$ diinkubasi pada suhu uji. Setelah suhu larutan subsrat mencapai suhu uji, sebanyak 0,2 ml enzim pektinesterase yang telah didialisis dimasukkan ke dalam larutan dan diinkubasi selama 30 menit kemudian diuji aktivitas enzim pektinesterase menggunakan metode Kertesz. Larutan substrat pektin 1\% tanpa penambahan enzim sebagai kontrol.

Penentuan kestabilan pH dan suhu enzim pektinesterase. Uji kestabilan $\mathrm{pH}$ enzim pektinesterase dilakukan pada pH 3-9 pada suhu optimum enzim (Hou dkk., 1997). Sebanyak 0,2 ml enzim pektinesterase dimasukkan ke dalam 0,2 $\mathrm{ml}$ buffer yang telah diatur suhunya. Inkubasi dilakukan selama 30 menit. Setelah didinginkan secara cepat, enzim pektinesterase dalam buffer diuji menggunakan metode titrasi Kertesz. Buffer yang digunakan untuk uji adalah 10 $\mathrm{mM}$ buffer sitrat (MERCK) pH 3, 4, 5, dan 6, $10 \mathrm{mM}$ buffer fosfat (MERCK) pH 7 dan 8, serta $10 \mathrm{mM}$ buffer Karbonatbikarbonat (MERCK) pH 9.

Kestabilan suhu enzim pektinesterase diuji pada suhu $30-90^{\circ} \mathrm{C}$ pada $\mathrm{pH}$ optimum (Saenz dkk., 2000). Sebanyak $0,2 \mathrm{ml}$ buffer sesuai $\mathrm{pH}$ optimum enzim dalam tabung reaksi diinkubasi dalam circulating bath (HAAKE DL 30) untuk mengatur suhu buffer mencapai suhu uji kemudian 0,2 ml enzim pektinesterase ditambahkan ke dalam buffer. Inkubasi dilakukan selama 30 menit kemudian larutan didinginkan secara cepat dan dilakukan pengujian aktivitas enzim sesuai metode titrasi Kertesz.

Penentuan kinetika enzim nilai $K_{\mathrm{M}}$ dan $V_{\text {maks }}$ PE. Larutan substrat pektin sitrus (SIGMA) dibuat dengan konsentrasi antara 0,25 - $10 \mathrm{mg} / \mathrm{ml}$ dalam larutan $\mathrm{NaCl}$ (MERCK) 0,1 M (pH 7,0), lalu dilakukan pengujian aktivitas enzim sesuai prosedurnya (Maria dkk., 2007). Setelah itu ditentukan aktivitas enzim pektinesterase $(\mathrm{u} / \mathrm{ml})$ pada masingmasing konsentrasi substrat. Nilai $\mathrm{K}_{\mathrm{M}}$ dan $\mathrm{V}_{\text {maks }}$ ditentukan berdasarkan persamaan kurva Lineweaver-Burk.

$$
\frac{1}{\mathrm{~V}}=\frac{1}{\mathrm{~V}_{\text {maks }}}+\frac{\mathrm{K}_{\mathrm{M}}}{\mathrm{V}_{\text {maks }}}\left(\frac{1}{[S]}\right)
$$




\section{HASIL DAN PEMBAHASAN}

\section{Screening Isolat Penghasil Enzim Pektinesterase Potensial untuk Klarifikasi Sari Buah Jeruk Keprok Garut}

Hasil pengujian menunjukkan bahwa keempat belas isolat mampu menghasilkan enzim pektinesterase. Seleksi isolat dilakukan untuk mendapatkan isolat terbaik yang dapat digunakan untuk memproduksi enzim pektinesterase dan diaplikasikan pada klarifikasi sari buah jeruk. Data aktivitas enzim pektinesterase $(\mathrm{u} / \mathrm{ml})$, jumlah sel akhir $(\mathrm{sel} / \mathrm{ml})$, dan kemampuan enzim dalam klarifikasi sari buah jeruk keprok garut dan pektin cair $1 \%$. ditampilkan dalam Tabel 1.

Aktivitas enzim pektinesterase (u/ml) dan jumlah sel akhir (sel/ml). Aktivitas enzim pektinesterase merupakan parameter utama dalam seleksi isolat uji karena enzim yang digunakan dalam tahap ini merupakan ekstrak enzim kasar yang kemungkinan tidak hanya mengandung enzim pektinesterase saja namun dapat mengandung enzim lain yang juga dapat berperan dalam klarifikasi sari buah jeruk. Aktivitas enzim pektinesterase dari isolat bervariasi antara $0,0100-0,0450 \mathrm{u} / \mathrm{ml}$. Dari empat belas isolat, hasil pengujian menunjukkan bahwa isolat AR 6 mempunyai aktivitas enzim pektinesterase tertinggi $(0,0450 \mathrm{u} / \mathrm{ml})$ dan diikuti oleh isolat AR $4(0,0283 \mathrm{u} / \mathrm{ml})$, dan KK $2(0,0267 \mathrm{u} /$ $\mathrm{ml}$ ). Penelitian lainnya juga melaporkan bahwa meskipun ditemukan 26 isolat Aspergillus niger yang diisolasi dari kulit jeruk mempunyai aktivitas pektinase namun hanya 6 isolat yang menunjukkan aktivitas yang tinggi (Truc dkk., 2011). Isolat AR 6 juga diketahui memiliki jumlah sel tertinggi, yaitu sebanyak $3,22 \cdot 10^{7} \mathrm{sel} / \mathrm{ml}$.

Kemampuan klarifikasi. Aplikasi enzim kasar ke dalam sari buah jeruk keprok garut dilakukan untuk mengetahui kemampuan enzim dalam klarifikasi sari buah jeruk. Menurut Ceci dan Lozano (2010), pektin yang larut dalam sari buah membuat sari buah sangat kental sehingga menghambat proses penyaringan. Penambahan enzim pektinase ke dalam sari buah jeruk akan menyebabkan penurunan viskositas sari buah jeruk. Hasil pengukuran viskositas sari buah jeruk menunjukkan bahwa sari buah jeruk yang diberi enzim kasar mengalami penurunan viskositas jika dibandingkan dengan kontrol kecuali untuk sari buah jeruk yang diberi perlakuan enzim kasar isolat KK 4, KK 2, AR 6, dan AR 5. Viskositas sari buah jeruk dengan perlakuan enzim bervariasi dari 0,898 - 1,210 cp. Penurunan viskositas juga terjadi setelah perlakuan enzim pektinase kasar dari A. japonicus 586 pada sari buah cupuacu dari Brazil (Teixeira dkk., 2011), serta enzim pektinolitik komersial pada sari buah lemon (Ucan dkk., 2014).

Semakin tinggi nilai transmitansi maka sari buah jeruk semakin jernih. Hasil pengujian transmitansi menunjukkan bahwa nilai transmitansi sari buah jeruk yang diberi enzim kasar lebih tinggi dibandingkan dengan sari buah jeruk

Tabel 1. Aktivitas enzim pektinesterase ( $\mathrm{u} / \mathrm{ml})$, jumlah sel akhir ( $\mathrm{sel} / \mathrm{ml})$, dan kemampuan enzim dalam klarifikasi sari buah jeruk keprok Garut dan pektin cair $1 \%$ pada masing-masing isolat

\begin{tabular}{lccccccc}
\hline \multirow{2}{*}{ Kode isolat } & Aktivitas enzim & Jumlah sel & \multicolumn{3}{c}{ Sari buah jeruk } & \multicolumn{2}{c}{ Pektin cair 1\% } \\
\cline { 4 - 7 } & $(\mathrm{u} / \mathrm{ml})$ & akhir (sel/ml) & Viskositas (cp) & $\% \mathrm{~T}$ & $\mathrm{TPT}\left({ }^{\circ} \mathrm{Brix}\right)$ & Viskositas (cp) & $\% \mathrm{~T}$ \\
\hline AR 1 & 0,0133 & $2,98.10^{7}$ & 0,938 & 2,60 & 8,00 & 1,230 & 83,10 \\
AR 2 & 0,0233 & $1,35.10^{7}$ & 0,912 & 2,90 & 8,00 & 1,120 & 83,80 \\
AR 3 & 0,0117 & $1,37.10^{7}$ & 0,896 & 2,60 & 8,00 & 1,170 & 83,80 \\
AR 4 & 0,0283 & $1,64.10^{7}$ & 0,930 & 2,70 & 8,00 & 1,200 & 83,20 \\
AR 5 & 0,0167 & $6,90.10^{5}$ & 1,210 & 2,90 & 8,00 & 1,210 & 83,00 \\
AR 6 & 0,0450 & $3,22.10^{7}$ & 1,080 & 2,80 & 8,00 & 1,180 & 83,00 \\
AR 7 & 0,0217 & $2,86.10^{7}$ & 0,923 & 2,50 & 8,00 & 1,220 & 83,40 \\
AR 8 & 0,0150 & $1,89.10^{7}$ & 0,905 & 2,60 & 8,00 & 1,220 & 83,40 \\
AR 9 & 0,0250 & $1,97.10^{7}$ & 0,925 & 2,40 & 8,00 & 1,170 & 83,80 \\
KK 1 & 0,0217 & $1,55.10^{7}$ & 0,904 & 2,50 & 8,00 & 1,200 & 83,40 \\
KK 2 & 0,0267 & $1,38.10^{7}$ & 0,951 & 2,50 & 8,00 & 1,200 & 83,20 \\
KK 3 & 0,0100 & $1,86.10^{7}$ & 0,917 & 2,40 & 8,00 & 1,460 & 83,30 \\
KK 4 & 0,0167 & $1,11.10^{7}$ & 0,947 & 2,70 & 8,00 & 1,220 & 83,30 \\
KK 5 & 0,0217 & $5,45.10^{6}$ & 0,900 & 2,50 & 8,00 & 1,170 & 83,00 \\
\hline Kontrol & & 0,946 & 1,90 & 9,00 & 1,200 & 82,90 \\
\hline
\end{tabular}


kontrol. Nilai transmitansi sari buah jeruk dengan perlakuan enzim bervariasi dari $2,40-2,90 \%$ dan penambahan enzim kasar isolat AR 2 memiliki nilai transmitansi paling tinggi $(2,90 \%)$

Hasil pengukuran nilai TPT pada sari buah jeruk yang diberi perlakuan enzim, yaitu $8^{\circ}$ Brix dan pada sari buah jeruk kontrol sebesar $9^{\circ}$ Brix. Semakin tinggi kadar sukrosa maka nilai ${ }^{\circ}$ Brix semakin meningkat. Penurunan nilai total padatan terlarut juga terjadi pada penelitian Iriani dkk. (2005), sari buah mangga kuini yang diberi penambahan pektinase mengalami penurunan total padatan terlarut selama penyimpanan. Aktivitas enzim mendegradasi pektin menjadi senyawa sederhana sehingga mengakibatkan penurunan total padatan terlarut.

Aktivitas depolimerisasi. Untuk membandingkan kemampuan enzim dalam depolimerisasi pektin dalam sari buah jeruk dengan pektin sintetis, maka dilakukan aplikasi enzim kasar ke dalam pektin cair 1\% dan dilakukan pengamatan pengaruh penambahan enzim kasar terhadap penurunan viskositas pektin cair 1\% dan \% transmitansi. Menurut Saranraj dan Naidu (2014) enzim pektinase merupakan enzim yang mendepolimerisasi pektin melalui reaksi hidrolisis dan transeliminasi dan juga dengan reaksi deesterifikasi, yang menghidrolisis ikatan ester antara gugus karboksil dan gugus metil pektin. Enzim kasar isolat AR 2 merupakan enzim yang menurunkan viskositas pektin cair $1 \%$ paling rendah, yaitu sebesar $1,120 \mathrm{cp}$. Nilai transmitansi pektin cair $1 \%$ dengan perlakuan enzim berkisar antara 83 $83,8 \%$. Pektin cair $1 \%$ dengan penambahan enzim kasar isolat AR 2 memiliki nilai transmitansi paling tinggi (83,8\%).

Berdasarkan hasil penelitian maka dipilih empat isolat uji untuk digunakan pada tahapan penelitian berikutnya yaitu isolat AR 2, AR 4, AR 6, dan KK 2. Isolat AR 4, AR 6, dan KK 2 dipilih karena merupakan tiga isolat bakteri dengan aktivitas enzim yang relatif paling tinggi. Isolat AR 6 juga memiliki jumlah sel per ml terbanyak dan nilai transmitansi pada sari buah jeruk keprok garut tertinggi kedua. Isolat AR 2 dipilih karena memiliki nilai transmitansi tertinggi baik pada sari buah jeruk keprok garut maupun pektin cair 1\% dan kemampuan enzim dalam menurunkan viskositas pada pektin cair $1 \%$.

\section{Pemurnian Parsial Enzim Pektinesterase Isolat AR 2, AR 4, AR 6, dan KK 2}

Hasil optimasi presipitasi enzim kasar dengan garam amonium sulfat pada konsentrasi kejenuhan amonium sulfat $50 \%, 60 \%, 70 \%$, dan $80 \%$ menunjukkan bahwa aktivitas tertinggi enzim pektinesterase isolat yang satu dengan yang lainnya berada pada fase kejenuhan ammonium sulfat yang berbeda-beda. Aktivitas enzim pektinesterase isolat AR 2,
AR 4, AR 6, dan KK 2 tertinggi masing-masing ditemukan pada fraksi kejenuhan $80 \% ; 70 \% ; 50 \%$; dan 60\% (Tabel 2). Joshi dkk. (2011) melaporkan bahwa PME yang dihasilkan oleh Aspergillus niger menunjukkan aktivitas enzim tertinggi pada fase kejenuhan ammonium sulfat $80 \%$. PME dari Cladosporium cladosporioides mempunyai aktivitas enzim tertinggi pada fase kejenuhan ammonium sulfat $60 \%$ (Bastos dkk., 2013).

Tabel 2. Pengaruh berbagai konsentrasi ammonium sulfat dalam pemurnian parsial enzim pektinesterase isolat AR 2, AR 4, AR 6, dan KK 2

\begin{tabular}{|c|c|c|}
\hline Kode isolat & $\begin{array}{c}\text { Konsentrasi ammonium } \\
\text { sulfat }(\%)\end{array}$ & $\begin{array}{l}\text { Aktivitas enzim } \\
\qquad(\mathrm{u} / \mathrm{ml})\end{array}$ \\
\hline \multirow[t]{4}{*}{ AR2 } & $50 \%$ & 0,0783 \\
\hline & $60 \%$ & 0,1100 \\
\hline & $70 \%$ & 0,1100 \\
\hline & $80 \%$ & 0,1200 \\
\hline \multirow[t]{4}{*}{ AR4 } & $50 \%$ & 0,0500 \\
\hline & $60 \%$ & 0,0400 \\
\hline & $70 \%$ & 0,0717 \\
\hline & $80 \%$ & 0,0200 \\
\hline \multirow[t]{4}{*}{ AR6 } & $50 \%$ & 0,1133 \\
\hline & $60 \%$ & 0,0867 \\
\hline & $70 \%$ & 0,1000 \\
\hline & $80 \%$ & 0,1100 \\
\hline \multirow[t]{4}{*}{ KK2 } & $50 \%$ & 0,0433 \\
\hline & $60 \%$ & 0,0933 \\
\hline & $70 \%$ & 0,0783 \\
\hline & $80 \%$ & 0,0867 \\
\hline
\end{tabular}

Pemurnian secara dialisis dilakukan menggunakan membran selofan. Membran selofan yang digunakan adalah membran selofan dengan cut off $12 \mathrm{kDa}$ sehingga dapat memisahkan protein dengan partikel non-protein dengan berat molekul lebih kecil dari $12 \mathrm{kDa}$. Protein yang merupakan enzim akan tertahan di dalam membran sedangkan partikel lain yang memiliki berat molekul lebih kecil dari $12 \mathrm{kDa}$ akan keluar dari membran. Jayani dkk., (2005) menyampaikan bahwa berat molekul sejumlah PE berkisar antara 35-50 kDa. Dialisis juga dilakukan untuk menghilangkan garam ammonium sulfat yang ada dalam ekstrak enzim kasar. Aktivitas enzim pektinesterase pada ekstrak enzim kasar, setelah presipitasi ammonium sulfat, dan setelah dialisis ditampilkan pada Tabel 3. Derajat kemurnian enzim didasarkan pada aktivitas spesifik, yaitu sejumlah unit 
enzim (u) per milligram protein. Dari data yang ditampilkan pada Tabel 3 dapat diketahui bahwa pemurnian parsial dapat meningkatkan aktivitas enzim.

Tabel 3. Aktivitas enzim pektinesterase pada tahap-tahap pemurnian

\begin{tabular}{|c|c|c|c|c|}
\hline $\begin{array}{l}\text { Kode } \\
\text { isolat }\end{array}$ & $\begin{array}{c}\text { Tahap } \\
\text { pemurnian }\end{array}$ & $\begin{array}{c}\text { Aktivitas } \\
\text { enzim }(\mathrm{u} / \mathrm{ml})\end{array}$ & $\begin{array}{l}\text { Protein } \\
(\mathrm{mg} / \mathrm{ml})\end{array}$ & $\begin{array}{c}\text { Aktivitas } \\
\text { spesifik }(\mathrm{u} / \mathrm{mg})\end{array}$ \\
\hline \multirow{3}{*}{ AR 2} & Enzim kasar & 0,023 & 2,156 & 0,0466 \\
\hline & $\begin{array}{l}\text { Presipitasi } \\
\left(\mathrm{NH}_{4}\right)_{2} \mathrm{SO}_{4} 80 \%\end{array}$ & 0,120 & 0,871 & 0,4851 \\
\hline & Dialisis & 0,400 & 0,790 & 1,7279 \\
\hline \multirow{3}{*}{ AR 4} & Enzim kasar & 0,028 & 2,108 & 0,0577 \\
\hline & $\begin{array}{l}\text { Presipitasi } \\
\left(\mathrm{NH}_{4}\right)_{2} \mathrm{SO}_{4} 70 \%\end{array}$ & 0,072 & 0,941 & 0,2746 \\
\hline & Dialisis & 0,350 & 0,866 & 1,4210 \\
\hline \multirow{3}{*}{ AR 6} & Enzim kasar & 0,045 & 2,118 & 0,0914 \\
\hline & $\begin{array}{l}\text { Presipitasi } \\
\left(\mathrm{NH}_{4}\right)_{2} \mathrm{SO}_{4} 50 \%\end{array}$ & 0,113 & 0,785 & 0,4917 \\
\hline & Dialisis & 0,333 & 0,710 & 1,5442 \\
\hline \multirow{3}{*}{ KK 2} & Enzim kasar & 0,027 & 2,054 & 0,0556 \\
\hline & $\begin{array}{l}\text { Presipitasi } \\
\left(\mathrm{NH}_{4}\right)_{2} \mathrm{SO}_{4} 60 \%\end{array}$ & 0,093 & 0,919 & 0,3632 \\
\hline & Dialisis & 0,317 & 0,817 & 1,3388 \\
\hline
\end{tabular}

Ekstrak enzim kasar mempunyai aktivitas enzim yang kecil karena banyak mengandung protein-protein non enzim yang dapat mengganggu aktivitas katalitik enzim. Penambahan ammonium sulfat berpengaruh terhadap protein yang terendapkan selama proses pemurnian sehingga pemurnian enzim dapat meningkat aktivitas enzim. Joshi dkk., (2011) mengemukakan bahwa pemurnian parsial enzim dapat meningkatkan kestabilan enzim. Hal tersebut karena beberapa inhibitor enzim yang mungkin berada dalam ekstrak enzim dapat dihilangkan selama pemurnian.

\section{Karakterisasi Enzim Pektinesterase Isolat AR 2, AR 4, AR 6 dan KK 2}

pH dan suhu optimum enzim pektinesterase. Karakterisasi enzim dilakukan untuk mengetahui kondisi optimal enzim yang dapat digunakan dalam aplikasi enzim di bidang industri. Nilai $\mathrm{pH}$ optimum merupakan $\mathrm{pH}$ yang dapat menyebabkan kecepatan reaksi enzim paling tinggi. Berdasarkan Gambar 1, $\mathrm{pH}$ optimum enzim pektinesterase isolat AR 2, AR 4, AR 6, dan KK 2 berturut-turut adalah 8; 7,5; 8,5; dan pH 6,5. Menurut Winarno (1986), pada enzim yang sama sering mempunyai $\mathrm{pH}$ optimum yang berbeda, tergantung dari asal enzim tersebut. Enzim pektinesterase dari bakteri Clostridium thermosaccharolyticum optimum pada pH 7 (Rijssel dkk., 1993), Clostridium thermosulfurogenes optimum pada pH 6,5 (Schink dan Zeikus, 1983), kapang Fusarium asiaticum optimum pada pH 6,5 (Glinka dan Liao, 2011), dan kapang Phytophthora infestans optimum pada $\mathrm{pH}$ 7 (Forster dan Rasched, 1985).

Suhu optimum merupakan suhu pada saat laju reaksi enzim paling tinggi mengubah substrat dan merupakan hasil kesetimbangan antara laju kenaikan aktivitas dan laju perusakan enzim (Bintang, 2010). Hasil pengujian suhu optimum dapat dilihat pada Gambar 2. Enzim pektinesterase isolat AR 2 dan isolat AR 6 memiliki suhu optimum $55^{\circ} \mathrm{C}$ sedangkan enzim pektinesterase isolat AR 4 dan isolat $\mathrm{KK}$ 2 memiliki suhu optimum $60^{\circ} \mathrm{C}$. Enzim pektinesterase dari sumber isolat yang berbeda juga menunjukkan suhu optimum yang berbeda pula antara lain enzim pektinesterase bakteri
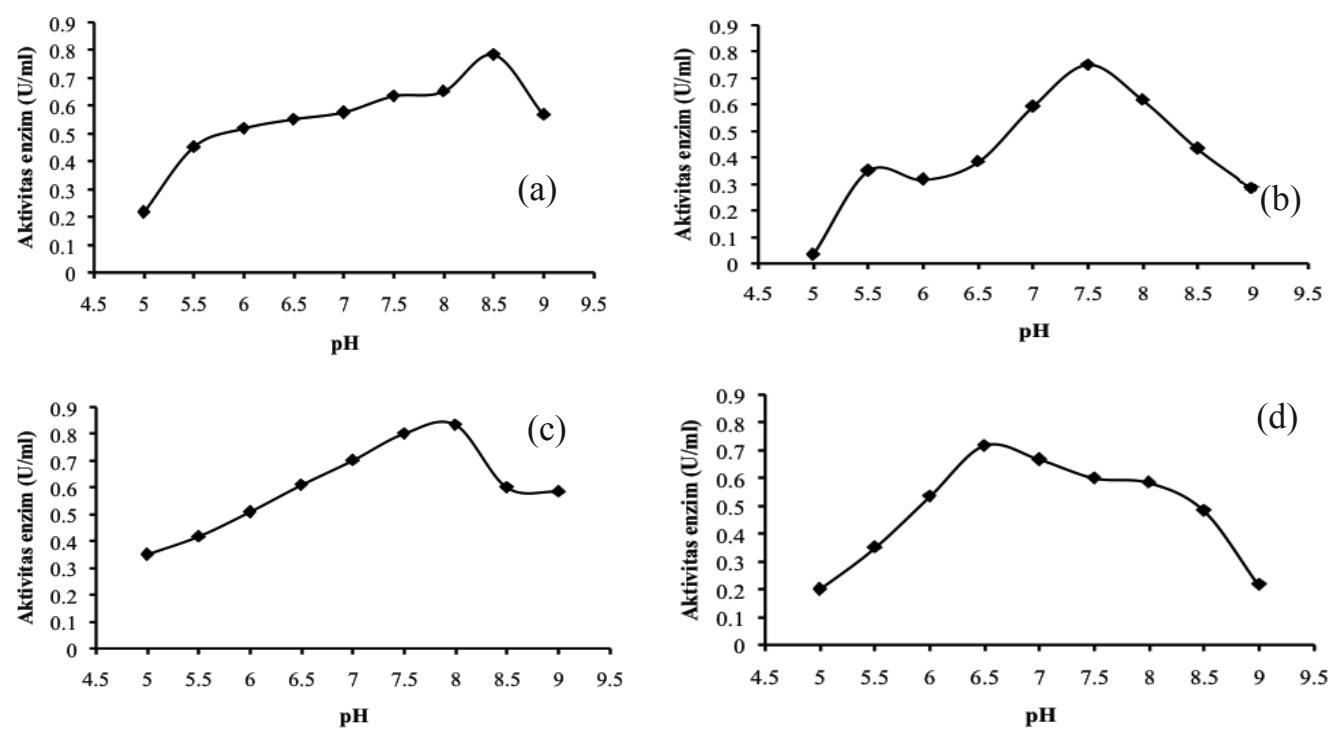

Gambar 1. Grafik pH optimum enzim pektinesterase isolat AR 2 (a), AR 4 (b), AR 6 (c), dan KK 2 (d) 

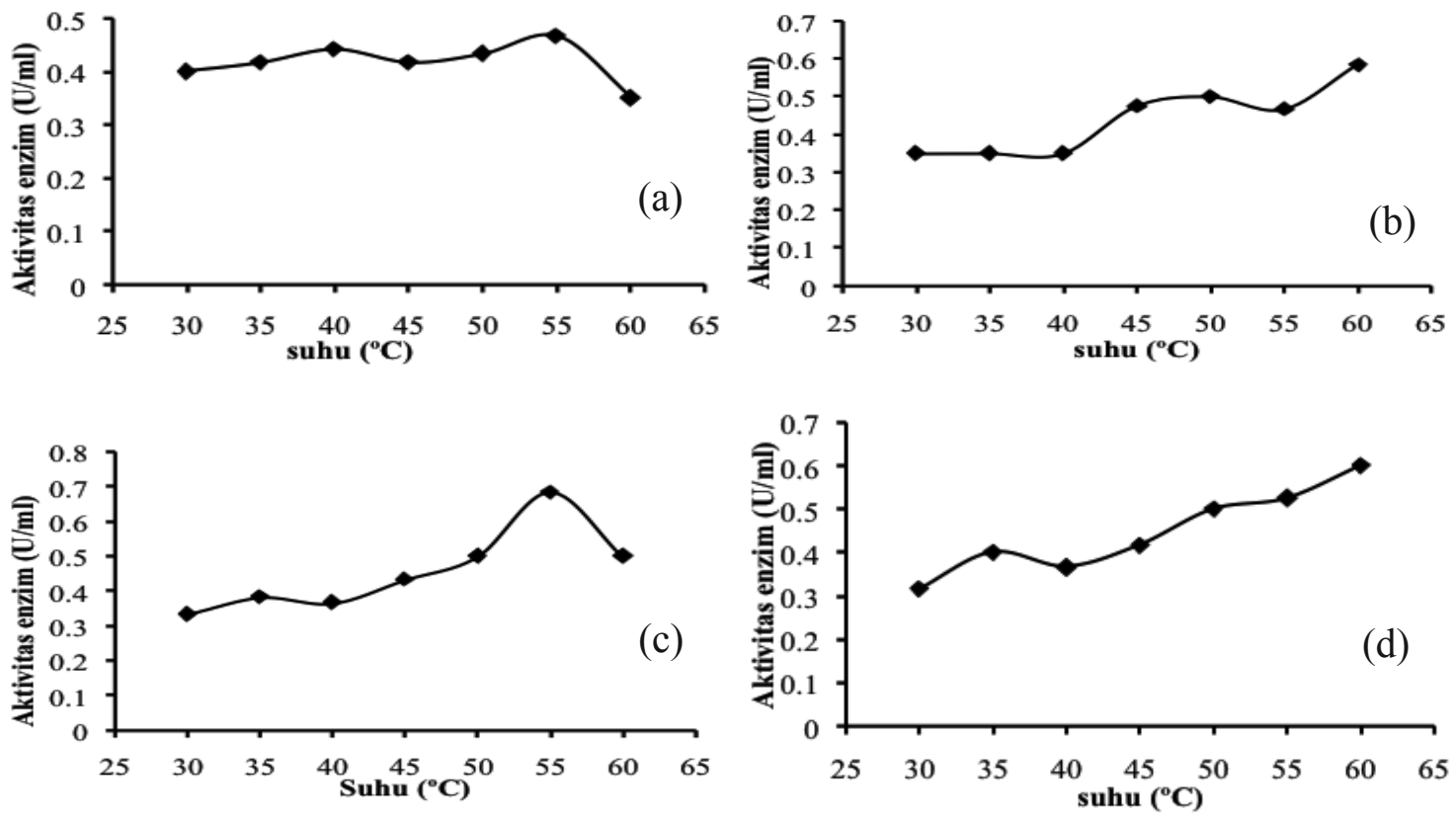

Gambar 2. Grafik suhu optimum enzim pektinesterase isolat AR 2 (a), AR 4 (b), AR 6 (c), dan KK 2 (d)

Clostridium thermosulfurogenes mempunyai suhu optimum pada suhu $70^{\circ} \mathrm{C}$ (Schink dan Zeikus, 1983) dan kapang $A$. niger strain MTCC 281 mempunyai suhu optimum pada suhu $50^{\circ} \mathrm{C}$ (Sharma dkk., 2011).

Kestabilan pH dan suhu enzim pektinesterase. Selain $\mathrm{pH}$ dan suhu optimum, faktor penting yang menentukan kualitas enzim dalam aplikasi di bidang industri adalah stabilitas enzim terhadap $\mathrm{pH}$ dan suhu. Stabilitas enzim adalah kemampuan enzim untuk menjaga struktur dan konformasinya pada kondisi lingkungan tertentu sehingga aktivitas tetap tinggi. $\mathrm{pH}$ rendah atau $\mathrm{pH}$ tinggi dapat menyebabkan terjadinya denaturasi yang akan mengakibatkan aktivitas enzim menurun (Poedjiadi, 1994). Pengujian stabilitas pH
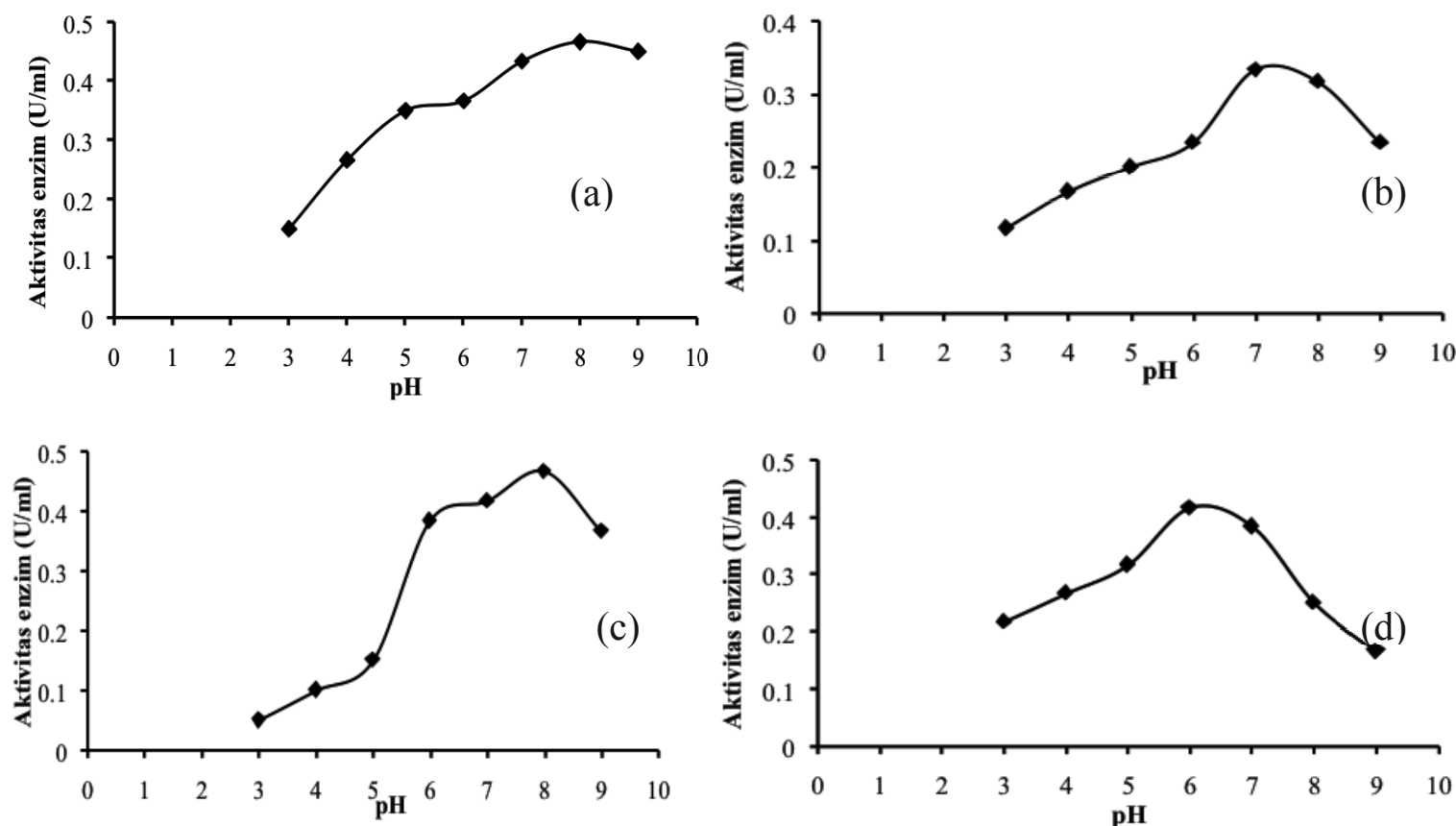

Gambar 3. Grafik kestabilan pH enzim pektinesterase isolat AR 2 (a), AR 4 (b), AR 6 (c), dan KK 2 (d) 
enzim pektinesterase menggunakan variasi pH buffer 3-9. Enzim pektinesterase isolat AR 2 stabil pada pH 4-9, enzim pektinesterase isolat AR 4 stabil pada rentang $\mathrm{pH}$ 4-9, aktivitas enzim pektinesterase isolat AR 6 stabil pada $\mathrm{pH}$ 6-9, sedangkan enzim pektinesterase isolat KK 2 menunjukkan aktivitas yang stabil pada pH 3-8 (Gambar 3). Pada rentang $\mathrm{pH}$ tersebut masing-masing enzim mempunyai aktivitas lebih dari 50\% dari nilai aktivitas tertingginya. Meskipun $\mathrm{pH}$ optimum enzim pektinesterase isolat AR 2, AR 4, AR 6, dan KK 2 berada pada rentang $\mathrm{pH}$ basa, namun hasil pengujian kestabilan $\mathrm{pH}$ menunjukkan bahwa enzim pektinesterase AR 2, AR 4, AR 6, dan KK 2 juga stabil pada pH asam. Enzim pektinesterase semua isolat masih menunjukkan aktivitas pada $\mathrm{pH} 3$ walaupun aktivitasnya rendah. Kestabilan enzim pada rentang $\mathrm{pH}$ yang luas merupakan kelebihan enzim untuk aplikasi di industri.

Kestabilan suhu merupakan salah satu karakteristik penting yang harus dimiliki enzim dalam aplikasi di industri. Aktivitas enzim pektinesterase isolat AR 2 stabil pada suhu $30-50^{\circ} \mathrm{C}$ dan inaktif pada suhu $80^{\circ} \mathrm{C}$, enzim pektinesterase isolat $\mathrm{AR} 4$ dan $\mathrm{KK} 2$ stabil pada suhu $30-60^{\circ} \mathrm{C}$ dan inaktif pada suhu $90^{\circ} \mathrm{C}$, sedangkan enzim pektinesterase isolat stabil pada suhu $30-60^{\circ} \mathrm{C}$ namun belum inaktif pada suhu $90^{\circ} \mathrm{C}$. Pada rentang suhu kestabilan tersebut masing-masing enzim mempunyai aktivitas lebih dari $75 \%$ dari nilai aktivitas tertingginya, sedangkan pada suhu di luar batas kestabilan enzim mempunyai aktivitas kurang dari 50\%. Hasil uji kestabilan suhu enzim pektinesterase isolat AR 2, AR 4, AR 6, dan KK 2 ditampilkan pada Gambar 4.
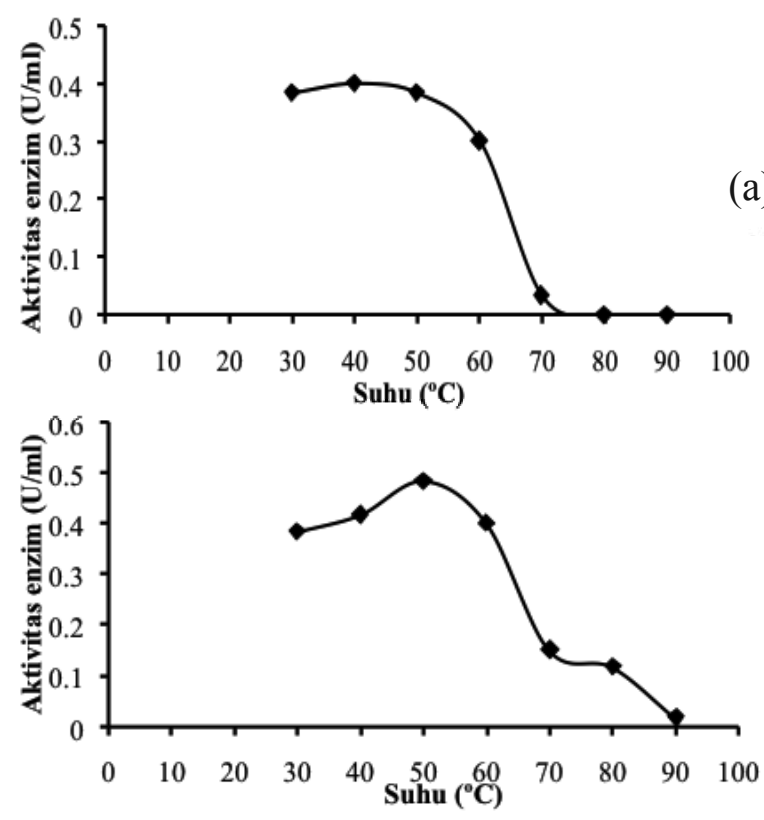

(a)

(c)
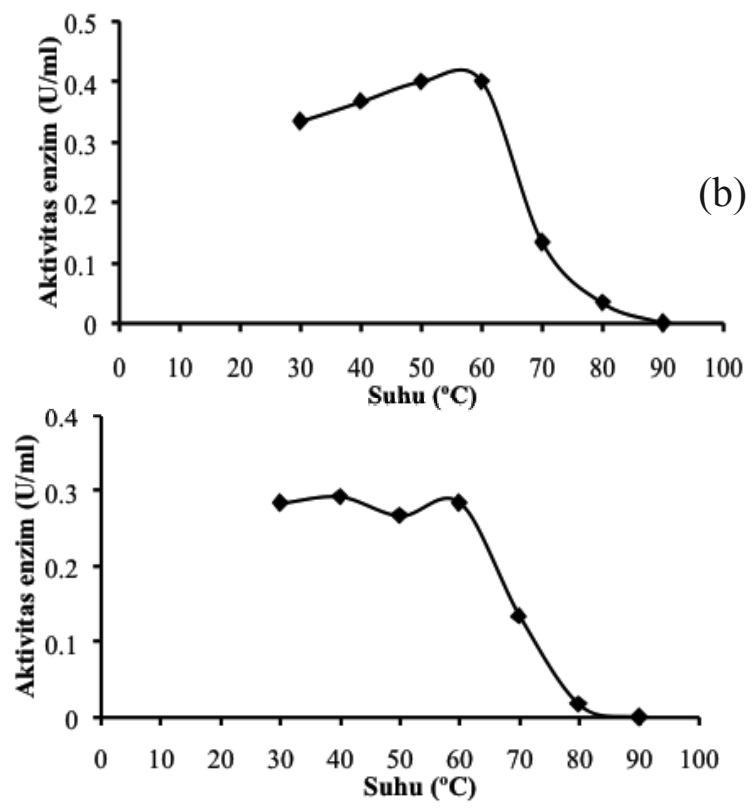

Kinetika enzim. Kinetika enzim berkaitan dengan kecepatan suatu enzim bekerja. Konstanta Michaelis Menten $\left(\mathrm{K}_{\mathrm{M}}\right)$ merupakan konsentrasi substrat untuk mencapai kecepatan aktivitas enzim setengah maksimum, sedangkan $\mathrm{V}_{\text {maks }}$ adalah kecepatan aktivitas enzim maksimal. $\mathrm{K}_{\mathrm{M}}$ merupakan suatu indikator kekuatan ikatan kompleks ES. Bila $\mathrm{K}_{\mathrm{M}}$ besar berarti ikatan kompleks ES lemah dan bila $\mathrm{K}_{\mathrm{M}}$ kecil ikatan ES kuat (Winarno, 1986). Nilai $\mathrm{K}_{\mathrm{M}}$ yang semakin kecil maka ikatan substrat dengan enzim akan semakin kuat sehingga akan mudah untuk menghasilkan produk. Nilai $\mathrm{K}_{\mathrm{M}}$ dan $\mathrm{V}_{\text {maks }}$ ditentukan melalui persamaan regresi linier grafik Lineweaver-Burk. Nilai $\mathrm{K}_{\mathrm{M}}$ dan $\mathrm{V}_{\text {maks }}$ enzim pektinesterase isolat AR 2, AR 4, AR 6, dan KK 2 dapat dilihat pada Tabel 4.

Tabel 4. Nilai $\mathrm{K}_{\mathrm{M}}(\mathrm{mg} / \mathrm{ml})$ dan $\mathrm{V}_{\text {maks }}(\mathrm{U} / \mathrm{ml})$ enzim pektinesterase isolat AR 2, AR 4, AR 6, dan KK 2

\begin{tabular}{ccc}
\hline Kode Isolat & $\mathrm{K}_{\mathrm{M}}(\mathrm{mg} / \mathrm{ml})$ & $\mathrm{V}_{\text {maks }}(\mathrm{U} / \mathrm{ml})$ \\
\hline AR 2 & 0,604 & 1,218 \\
AR 4 & 0,338 & 0,826 \\
AR 6 & 0,971 & 0,969 \\
KK 2 & 0,392 & 1,080 \\
\hline
\end{tabular}

Berdasarkan nilai $\mathrm{K}_{\mathrm{M}}$, enzim pektineterase isolat $\mathrm{AR}$ 4 memiliki nilai $\mathrm{K}_{\mathrm{M}}$ yang paling rendah yang berarti enzim pektinesterase isolat AR 4 memiliki afinitas yang paling kuat terhadap pektin dibanding enzim pektinesterase isolat lainnya, namun dalam proses klarifikasi sari buah jeruk keprok garut dibutuhkan enzim pektinesterase yang tahan terhadap

(d)

Gambar 4. Grafik kestabilan suhu enzim pektinesterase isolat AR 2 (a), AR 4 (b), AR 6 (c), dan KK 2 (d) 
kondisi proses baik terhadap suhu maupun $\mathrm{pH}$ lingkungan. Menurut Hui dkk. (2006), pH sari buah jeruk berkisar 3,64,3 sedangkan suhu klarifikasi sari buah menurut Ceci dan Lozano (2010), berkisar antara $45-50^{\circ} \mathrm{C}$. Berdasarkan hasil karakaterisasi enzim pektinesterase dari isolat terpilih, enzim pektinesterase isolat KK 2 memiliki karakteristik yang paling mendekati kondisi klarifikasi sari buah jeruk dibandingkan enzim pektinesterase isolat lainnya. Nilai $\mathrm{pH}$ optimum enzim pektinesterase isolat KK 2 pada $\mathrm{pH}$ 6,5 dan stabil pada $\mathrm{pH}$ 3-8. Enzim pektinesterase isolat $\mathrm{KK} 2$ bersifat termostabil karena memiliki suhu optimum pada suhu $60^{\circ} \mathrm{C}$ dan stabil pada suhu $30-60^{\circ} \mathrm{C}$. Enzim pektinesterase isolat $\mathrm{KK} 2$ memiliki nilai $\mathrm{K}_{\mathrm{M}}$ sebesar 0,392 $(\mathrm{mg} / \mathrm{ml})$ yang merupakan nilai $\mathrm{K}_{\mathrm{M}}$ terendah kedua dibandingkan enzim pektinesterase isolat $\mathrm{AR} 2, \mathrm{AR}$ 4, dan AR 6. Disamping itu, isolat KK 2 memiliki waktu optimum produksi enzim yang cepat, yaitu pada jam ke-7. Waktu pemanenan yang lebih cepat akan menghemat biaya produksi enzim.

\section{KESIMPULAN}

Hasil screening didapatkan isolat AR 2, AR 4, AR 6, dan KK 2 sebagai isolat penghasil enzim pektinesterase yang berpotensi dalam proses klarifikasi sari buah jeruk keprok garut. Aktivitas enzim pektinesterase isolat AR 2, AR 4, AR 6 dan KK 2 berturut-turut optimum pada $\mathrm{pH}$ 8; $\mathrm{pH} 7,5$; $\mathrm{pH} 8,5$; dan $\mathrm{pH} 6,5$ serta stabil pada $\mathrm{pH} 4-9, \mathrm{pH} 4-9$, pH 6-9, dan $\mathrm{pH}$ 3-8. Suhu optimum enzim pektinesterase isolat AR 2, AR 4, AR 6 dan KK 2 berturut-turut adalah $55^{\circ} \mathrm{C}, 60^{\circ} \mathrm{C}, 55^{\circ} \mathrm{C}$, dan $60^{\circ} \mathrm{C}$. Enzim pektinesterase isolat AR 2 stabil pada suhu 30$50^{\circ} \mathrm{C}$ dan inaktif pada suhu $80^{\circ} \mathrm{C}$, enzim pektinesterase isolat AR 4 dan KK 2 stabil pada suhu $30-60^{\circ} \mathrm{C}$ dan inaktif pada suhu $90^{\circ} \mathrm{C}$, sedangkan enzim pektinesterase isolat AR 6 stabil pada suhu $30-60^{\circ} \mathrm{C}$ namun belum inaktif pada suhu $90^{\circ} \mathrm{C}$. Nilai konstanta Michaelis-Menten $\left(\mathrm{K}_{\mathrm{M}}\right)$ enzim pektinesterase isolat $\mathrm{AR} 2$, AR 4, AR 6, dan KK 2 berturut-turut adalah 0,$604 ; 0,338 ; 0,971$; dan 0,392 $\mathrm{mg} / \mathrm{ml}$. Sedangkan nilai kecepatan maksimum $\left(\mathrm{V}_{\text {maks }}\right)$ enzim pektinesterase isolat AR 2, AR 4, AR 6, dan KK 2 berturut-turut adalah 1,218; 0,826; 0,969; dan 1,080 U/ml. Enzim pektinesterase isolat KK 2 memiliki karakteristik yang paling sesuai untuk aplikasi dalam klarifikasi sari buah jeruk keprok garut dibandingkan dengan enzim pektinesterase isolat lainnya.

\section{UCAPAN TERIMA KASIH}

Peneliti mengucapkan terima kasih kepada Universitas Sebelas Maret Surakarta yang telah membiayai penelitian ini melalui skim Hibah Riset Insentif Star-Up Dana PNBP UNS dengan nomor kontrak penelitian 858/UN27.11/PN/2014.

\section{DAFTAR PUSTAKA}

Anisa, S.K. dan Girish, K. (2014). Pectinolytic activity of Rhizopus sp., and Trichoderma viride. International Journal of Research in Pure and Applied Microbiology 4(2): 28-31.

Badan Pusat Statistik Kabupaten Garut (2014). Garut dalam Angka 2014. Badan Pusat Statistik Kabupaten Garut, Garut.

Basak, S. dan Ramaswamy, H.S. (2001). Pulsed high pressure inactivation ofpectin methyl esterase in single strengthand concentrated orange juices. Canadian Biosystem Engineering 43: 325-329.

Bastos, S.C., Pimenta, C.J., Dias, D.R., Chalfoun, S.M., Angelico, C.L. dan Tavares, L.S. (2013). Pectinases from a new strain of Cladosporium cladosporioides (Fres.) De Vries isolated from coffee bean. World Journal of Agricultural Sciences 9(2): 167-172.

Benitez, E.I dan Lozano, J.E. (2006). Influence of the soluble solids on the zeta potential of a cloudy apple juice. Latin America Applied Research 36: 163-168.

Bhardwaj, V. dan Garg, N. (2010). Exploitation of microorganism for isolation and screening of pectinase from environment. Globelics 8: 1-16.

Bintang, M. (2010). Biokimia Teknik Penelitian. PT Gelora Aksara Pratama, Jakarta.

Ceci, L.N. dan Lozano, J.E. (2010). Use of enzymes for noncitrus juice production. Enzyme in Fruit and Vegetable Processing- Chemistry and Engineering Aplication. Taylor and Francis Group. New York.

Cornick, N.A., Jensen, N.S., Stahl, D.A., Hartman, P.A. dan Allison, M.J. (1994). Lachnospira pectinoschiza sp. nov., an anaerobic pectinophile from the pig intestine. International Journal of System Bacteriology 44: 87-93.

Dixit, S., Upadhyay, S.K., Singh, H., Pandey, B., Chandrashekar, K. dan Verma, P. C. (2013). Pectin methylesterase of Datura species, purification, and characterization from Datura stramonium and its application. Plant Signaling and Behavior 8: 1-7.

Egas, M.C.V., Costa, M.S., Cowan, D.A. dan Pires, E.M.V. (1998). Extracellular $\alpha$-amylase from Thermus filiformis Ork A2: purification and biochemical characterization. Extremophiles 2: 23-32.

Forster, H. (1988). Pectinesterase from Phytophthora infestans. Methods in Enzymology 161: 355-357.

Forster, H. dan Rasched, I. (1985). Purification and characterization of extracellular pectinesterases from Phytophthora infestans. Plant Physiology 77: 109-112. 
Frittrang, A.K., Deising, H. dan Mendgen, K. (1992). Characterization and partial purification of pectinesterase, a differentiation-specific enzyme of Uromyces viciae-fabae. Journal of General Microbiology 138: 2213-2218.

Gainvors, A., Frezier, V., Lemaresquier, H., Lequart, C., Aigle, M. dan Belarbi, A. (1994). Detection of polygalacturonase, pectin lyase and pectinesterase activities in Saccharomyces cerevisiae strain. Yeast 10: 1311-1319.

Gaur, D., Jain, P.K., Sisodia, Y.S. dan Bajapai, V. (2012). Estimation of extracellular lipolytic enzyme activity by thermophilic Bacillus sp. isolated from arid and semiarid region of Rajasthan, India. Journal of Microbiology, Biotechnology and Food Science 2: 619-633.

Glinka, E.M. dan Liao, Y. (2011). Purification and partial characterisation of pectin methylesterase produced by Fusarium asiaticum. Fungal Biology 115(11): 11121121.

Hadj-Taieb, N., Ayadi, M., Trigui, S., Bouabdollah, F. dan Gargouri, A. (2002). Hyperproduction of pectinase activities by fully constitutive mutant (CT 1) of Penicillium occitanis. Enzyme and Microbial Technology 30: 662-666.

Hanif, Z. dan Zamzami, L. (2012). Trend impor jeruk dan posisi Indonesia sebagai produsen jeruk dunia. http:// balitjestro.litbang.deptan.go.id/id/510.html. [6 Febuari 2014].

Hou, W.N., Jeong, Y., Walker, B.L., Wei, C.I. dan Marshall, M.R. (1997). Isolation and characterization of pectinesterase from valencia orange. Journal of Food Biochemistry 21: 309-333.

Hui, Y. H., Barta, J., Cano, P., Gusk, T.W., Sidhu, J. S. dan Sinha, N.K. (2006). Handbook of Fruit and Fruit Processing. Blackwell Publishing, USA.

Ingallinera, B., Barbagallo, R.N., Spagna, G., Palmeri, R. dan Todaro, A. (2005). Effects of thermal treatments on pectinesterase activity determined in blood oranges juices. Enzyme and Microbial Technology 36: 258-263.

Iriani, E.S., Said, E.G., Suryani, A. dan Setyadjit (2005). Pengaruh penambahan konsentrasi pektinase dan kondisi inkubasi terhadap rendemen dan mutu jus mangga kuini (Mangifera odorata Griff). Jurnal Pascapanen 2: 11-17.

Janani, L.K., Kumar, G. dan Rao, K.V.B. (2011). Screening of pectinase producing microorganisms from agricultural waste dump. Asian Journal of Biochemical and Pharmaceutical Research 1: 329-337.
Jayani, R.S., Saxena, S. dan Gupta, R. (2005). Microbial pectinolytic enzymes : a review. Process Biochemistry 40: 2931-2944.

Joshi, V.K., Parmar, M. dan Rana, N. (2011). Purification and characterization of pectinase produced from apple pomace and evaluation of its efficacy in fruit juice extraction and clarification. Indian Journal of Natural Producs and Resources 2(2): 189-197.

Karam, N.E. dan Belarbi, A. (1995). Detection of polygalacturonase and pectinesterases in lactic acid bacteria. World Journal of Microbiology and Biotechnology 11: 559-563.

Karangwa, E., Rao, L.D.S., Nshimiyimana, M.B.K., Foh, L.L., Xia, S.Q. dan Zhang, X.M. (2010). Optimization of processing parameters for clarification of blended carrot-orange juice and improvement of its carotene content. Journal of Food Science and Technology 2: 268-278.

Kawano, C.Y., Chellegatti, M.A.S.C., Said, S. dan Fonseca, M.J.V. Comparative study of intracellular and extracellular pectinases produced by Penicillium frequentans. Biotechnology and Applied Biochemistry 29: $133-140$.

Laurent, F., Kotoujansky, A. dan Bertheau, Y. (2000). Overproduction in Escherichia coli of the pectin methylesterase a from Erwinia chrysanthemi 3937: one-step purification, biochemical characterization, and production of polyclonal antibodies. Canadian Journal of Microbiology 46: 474-480.

Maldonado, M.C., Saad, A.M.S. dan Callieri, D.A.S. (1994). Purification and characterization of pectinesterase produced by a strain of Aspergillus niger. Current Microbiology 24: 193-196.

Maldonaldo, M.S. dan Saad, A.M.S. (1998). Production of pectinesterase and polygalacturonase by Aspergillus niger in submerged and solid state systems. Journal of Industrial Microbiology and Biotechnology 20: 34-38.

Maria, A, Vera, V., Montoya, J.A.S., Calva, G.C. dan Ramirez, E.G.R. (2007). Extraction, thermal stability, and kinetic behavior of pectinmethylesterase from hawthorn (Crataegus pubescens) fruit. LWT-Food Science and Technology 40(2): 278-284.

Minh, N.P. (2014). Enzymatic pectinase application in extraction and purification of juice turbidity from red rose apple pulp (Syzygium malaccensis). International Journal of Multidisciplinary Research and Development 1(4): 45-51. 
Pitkanen, K., Heikinheimo, R. dan Pakkanen, R. (1992). Purification and characterization of Erwinia chrysatnthemi B374 pectin methylesterase produced by Bacillus subtilis. Enzyme and Microbial Technology 14: 832-836.

Poedjiadi, A. (1994). Dasar-Dasar Biokimia. UI-PRESS, Jakarta.

Rai, P., Majumdar, G.C., Jayanti, V.K., Dasgupta, S. dan De, S. (2006). Alternatif pretreatment methods to enzimatic treatment for clarification of mosambi juice using ultrafiltration. Journal of Food Process Engineering 9: 202-218.

Raj, A.A.S., Rubila, S., Jayabalan, R. dan Ranganathan, T.V. (2012). A review on pectin: chemistry due to general properties of pectin and its pharmaceutical uses. Open Acces Scientific Reports 1(12): 1-4.

Rijssel, M.V., Gerwig, G.J. dan Hansen, T.A. (1983). Isolation and characterization of an extracellular glycosylated protein complex from Clostridium thermosaccharolyticum with pectin methylesterase and polygalacturonatehydrolase activity. Applied and Envronmental Microbiology 59: 828-836.

Sáenz, J.M., Téllez, A., Garza, H., Reyes, M., ContrerasEsquivel, J.C. dan Aguilar, C.N. (2000). Purification and some properties of pectinesterase from potato (Solanum tuberosum L.) alpha cultivar. Brazilian Archives of Biology and Technology 43(4): 393-398.

Saranraj, P. dan Naidu, M.A. (2014). Microbial pectinases: a review. Global Journal of Traditional Medicinal System 3(2): 1-9.

Schell, M.A., Denny, T.P. dan Huang, J. (1994). Extracellular virulence factors of Pseudomonas solanacearum: role in disease and their regulation. Dalam: Kado, C.I. dan Crosa, J.H (ed.). Mol Mech Bacterial Virulence, hal. 311-24. Kluwer Academic Press, Netherlands.

Schink, B. dan Zeikus, J. G. (1983). Characterization of pectinolytic enzymes of Clostridium thermosulfurogenes. FEMS Microbiology Letters 17: 295-298.

Semenova, M.V., Grishutin, S.G., Gusakov, A.V., Okunev, O.N. dan Sinitsyu, A.P. (2003). Isolation and properties of pectinases from the fungus Aspergillus japonicus. Biochemistry 68: 559-569.
Sharma, N.R., Sasankan, A., Singh, A. dan Soni, G. (2011). Production of polygalacturonase and pectin pethyl esterase from agrowaste by using isolates of Aspergillus niger. Insight Microbiology 1(1): 1-7.

Sharma, P.K. dan Chand, D. (2012). Pseudomonas sp. xylanase for clarification of mousambi and orange fruit juice. International Journal of Advancements in Research and Technology 1: 1-3.

Soelarso, B. (1996). Budidaya Jeruk Bebas Penyakit. Kanisius, Yogyakarta.

Sudarmadji, S., Haryono, B. dan Suhardi. (2010). Prosedur Analisis untuk Bahan Makanan dan Pertanian. Liberty, Yogyakarta.

Teixeira, M.F.S., Andrade, J.S., Fernandes, O.C.C., Duran, N. dan Filho, J.L. (2011). Quality attributes of cupuacu juice in response to treatment with crude enzyme extract produced by Aspergillus japonicus 586. Enzyme Research 2011: 1-6.

Truc, T.T., Nguyet, L.V.H. dan Muoi, N.V.( 2011). Isolation and screening of Aspergillus niger strain for biosynthesis of pectin methylesterase from peel of some apple and fig (Ficus racemosa). Journal of Food Science and Technology 49(1A): 453-458.

Uçan, F., Akyildiz, A. dan ALçam. E. (2014). Effects of different enzymes and concetrations in the production of clarified lemon juice. Journal of Food Processing 2014: 1-14.

Widowati, E., Utami, R., Nurhartadi, E., Andriani, M.A.M. dan Wigati, A.W. (2014). Produksi dan karakterisasi enzim pektinase oleh bakteri pektinolitik dalam klarifikasi jus jeruk manis (Citrus sinensis). Jurnal Aplikasi Teknologi Pangan 3(1): 16-20.

Winarno, F.G. (1986). Enzim Pangan. Gramedia Pustaka Utama, Jakarta.

Yusak, Y. (2004). Pengaruh suhu dan pH buffer asetat terhadap hidrolisa CMC oleh enzim selulase dari ekstrak Aspergillus niger dalam media campuran onggok dan dedak. Jurnal Sains Kimia 8: 35-37.

Zamost, B., Nielsen, H.K. dan Starnes, R. (1991). Thermostable enzymes for industrial applications. Journal of Industrial Microbiology 8: 71-81. 